\title{
INDUSTRY OR CLASS CLEAVAGES OVER TRADE POLICY? EVIDENCE FROM THE BRITISH GENERAL ELECTION OF 1923
}

Douglas A. Irwin

Working Paper No. 5170

\author{
NATIONAL BUREAU OF ECONOMIC RESEARCH \\ 1050 Massachusetts Avenue \\ Cambridge, MA 02138 \\ July 1995
}

I wish to thank Gene Grossman and Mark Thomas for their helpful comments on an earlier draft of this paper. This paper is part of NBER's research program in International Trade and Investment. Any opinions expressed are those of the author and not those of the National Bureau of Economic Research.

() 1995 by Douglas A. Irwin. All rights reserved. Short sections of text, not to exceed two paragraphs, may be quoted without explicit permission provided that full credit, including $($ ) notice, is given to the source. 


\title{
INDUSTRY OR CLASS CLEAVAGES OVER \\ TRADE POLICY? EVIDENCE FROM THE \\ BRITISH GENERAL ELECTION OF 1923
}

\begin{abstract}
Economists and political scientists have frequently attempted to determine whether trade policy-related political action takes place along factor-lines (such as capital versus labor, as implied by the Stolper-Samuelson theorem) or along industry-lines (as implied by models with imperfect factor mobility). This paper examines voting patterns in the British general election of 1923, an election that hinged on free trade versus protection. The election provides an opportunity to distinguish between the two hypotheses because either an industry or a factor alignment among voters is plausible: rigidities in the interwar labor market have often been discussed, and electoral politics has often been viewed as having a class basis. This paper exploits data from the British census of 1921, which divides the population into categories of occupation (by industry) and categories of economic class (by income and/or skill level), and relates these data to cross-country variation in voting for the contending political parties. The results indicate that county differences in the occupational structure of the electorate account for the election outcome better than differences in class structure.
\end{abstract}

Douglas A. Irwin Graduate School of Business University of Chicago 1101 East 58th Street

Chicago, IL 60637 and NBER 


\section{Industry or Class Cleavages over Trade Policy? \\ Evidence from the British General Election of 1923}

\section{Introduction}

The Stolper-Samuelson relationship between output prices and factor rewards is central to any discussion of the political economy of trade policy. This relationship describes the economic stakes faced by the various factors of production that will ultimately interact in the political arena in the actual determination of policy.

These factors will have different economic interests -- and therefore will be aligned in different political coalitions -- depending upon the configuration of factor intensity, substitutability, and specificity across sectors. If factors are perfectly mobile across sectors, as assumed in the Heckscher-Ohlin model, for example, economic interests differ between factors of production (such as labor and capital) regardless of their industry of current employment. If factors are imperfectly mobile across sectors, then economic interests will be organized along industry lines with different factors of production (such as labor and capital in the steel industry, for example) seeking the same policy.

Economists and political scientists have tried to assess whether trade-related political behavior takes place more along sectoral (industry) lines or along factor (class) lines. Magee (1978) examined testimony before the House Ways and Means Committee on the Trade Reform Act of 1973 and found that, in 19 of 21 industries, trade unions (representing labor) took the same position as management and trade associations (representing the owners of capital). Rogowski (1989), by contrast, argues that political alignments in various countries over the last century can be best interpreted through the mobile factor Heckscher-Ohlin framework, although 
he performs no explicit test of this view.'

This paper provides some additional evidence on such political "cleavages" in the context of a simple institutional mechanism for observing economic interests: a direct election. The British general election of 1923 , an election that hinged on the issue of free trade and protection, provides a revelation mechanism such that the economic interests of the electorate can potentially be determined from cross-sectional voting patterns. Because the costs of voting are low, elections can increase the participation of free-trade segments of the electorate that, owing to the free rider problem, are commonly thought to be underrepresented in the political process. Thus, elections provide a setting relatively free from the complications of political structure, where, for example, the power of interest group lobbying and the ability of coalitions to organize can be decisive, and thereby provide a sharper view of the underlying economic interests of the electorate than would otherwise be the case. ${ }^{2}$

Furthermore, this particular election provides a reasonably fair opportunity to distinguish between the two hypotheses because either an industry or a factor alignment among voters is a plausible source of the election outcome. The institutional rigidities of the British interwar labor market often discussed by economic historians, such as Thomas (1992), suggest imperfect intersectoral mobility that would define economic interests in terms of industry of employment. Alternatively, Pulzer's (1967, p. 98) widely quoted claim -- "class is the basis of British party

1 In this context, Alt and Gilligan (1994) provide an overview of how economic interests and political organization costs affect the formation of trade policy.

2 Legislative voting, a common method of determining commercial policy prior to World War II, provides imperfect information on such political economy cleavages because of uncertainty about whether such votes reflect the ideology of legislators, log rolling within or between political parties, the pressure of particular interest groups, or the economic interests of constituents. 
politics; all else is embellishment and detail" -- is generally accepted by political scientists as describing elections prior to World War II and points to electoral divisions between unskilled labor, skilled labor, and the upper classes.

This paper addresses this question by exploiting data from the British census of 1921 , which divides the population into categories of occupation (by industry) and categories of economic class (by income and/or skill level). These data are then related to cross-county variation in voting for the contending political parties to determine which set of characteristics best describes the election outcome. The results indicate that county differences in the occupational structure of the electorate account for the election outcome far better than differences in class structure.

Section II presents some historical background on the general election of 1923 . Section III provides econometric evidence on how voting patterns in England relate to the employment or class characteristics of constituents in a given county. Section IV summarizes the results and speculates about their implications for our understanding of the political economy of trade policy.

\section{Historical Background}

During the half century of prosperity that followed the repeal of the Corn Laws in 1846, Free Trade (as it was often spelled) was taken as an article of faith in British politics. Britain's manufacturing superiority ensured that sizeable export industries lent the policy their unquestioned support. The consumer and labor interest in cheap food provided an even broader base of popular backing. Indeed, for the second half of the nineteenth century, free trade was essentially a closed political question. Although support for the policy wavered slightly during the 
1880s, a period of economic instability and growing import competition due to foreign industrialization, proposals for Tariff Reform (such as reciprocity) failed to make any serious impression until the turn of the century. ${ }^{3}$

The few opponents of free trade -- an eclectic group of protectionists, imperialists, and landed aristocrats -- found their home in the Conservative party, the traditional supporters of agricultural protection. Because these opponents had quite different interests, however, the meaning of "tariff reform" as advocated by the Conservatives was never entirely clear: protectionists wanted higher tariffs for bargaining purposes or to halt import penetration, imperialists wanted higher tariffs to create preferences to unite the Empire, and the aristocracy wanted higher tariffs on agricultural goods to preserve their position in society. All that one could really conclude is that tariff reformers rejected "Free Trade dogma" and wanted to introduce a higher tariff in some form or another.

By the turn of the century, these varied groups within the Conservative party grew in strength as foreign competition intensified and imperial sentiments deepened. This enabled them to seize opportunities to bring their proposals to the top of the political agenda. In three elections in the first quarter of the twentieth century -- 1906, 1910, and 1923 -- the Conservatives sought electoral support under the banner of "Tariff Reform." Each time they failed. In 1903, the Conservative party split over Joseph Chamberlain's scheme of tariffs on food imports to create imperial preferences and tariffs on manufactured imports to protect domestic producers. Conservatives fought the 1906 general election on Chamberlain's platform, but were crushed by

${ }^{3}$ Bhagwati and Irwin (1987) examine the parallels and contrasts between the British debate over reciprocity and foreign unfair trade practices in the late nineteenth century and the similar American debate in the late twentieth century. 
the reinvigorated Liberal party, long-time supporters of free trade, as analyzed in Irwin (1994). In January 1910 , in an election campaign dominated by the controversy over the powers of the House of Lords, the Conservatives again rallied around the cause of tariff reform. They met electoral defeat once again, though by a lesser margin than in 1906 .

The situation was somewhat different in 1923. In the years after World War I, the central problem in Britain was unemployment. The jobless rate jumped from under 5 percent in 1920 to over 15 percent in 1922, substantially above what it had been during the pre-war era. The underlying cause of the severe downturn was the reversal of the brief, inflationary boom that immediately followed the war. Unemployment soared as declines in money wages could not keep pace with falling prices. The political parties lacked any compelling proposals to deal with the situation, and hence the Conservatives turned once again to import protection.

This turn was facilitated by the experience with widespread controls and regulations on foreign trade that had been introduced during the war. The post-war coalition government retained some of these protectionist measures, such as the Safeguarding of Industries Act of 1921, although Capie (1983) finds that these tariffs affected rather few goods and were relatively minor in impact. After the collapse of Lloyd George's coalition in 1922 prompted a general election, the Conservatives (under Andrew Bonar Law) captured a majority of seats in the House of Commons. Bonar Law had pledged during the campaign not to engage in tariff reform, but poor health forced his replacement as Prime Minister by Stanley Baldwin, a tariff reformer, in May 1923. Baldwin felt bound by Bonar Law's pledge during the life of the current parliament.

But as the unemployment rate ticked upward again in the third quarter of 1923, Baldwin became convinced that higher tariffs were the cure to Britain's maladies. In October at the 
Conservatives's annual party conference, Baldwin declared:

Now from what I have said I think that you will realize that to me, at least, this unemployment problem is the most crucial problem of our country. I regard it as such. I can fight it. I am willing to fight it. I cannot fight it without weapons. . . . And I have come to the conclusion myself that the only way of fighting this subject is by protecting the home market. [Quoted in Snyder (1944), p. 141.]

For this reason, Baldwin soon dissolved parliament and sought from the electorate a mandate to pursue tariff revision. Of course, there was also a political motivation for this move. Baldwin sought to strengthen his hand by choosing an issue that might unite the Conservatives and split the Liberals.

According to A. J. P. Taylor (1965, p. 208), the general election of 1923 "was the only election in British history, fought solely and specifically on Protection." Once a radical cause for reformers, free trade had long been the status quo and, in light of contemporary economic conditions, appeared to be a rather tired and out-dated symbol of laissez faire. Free trade had lost its special aura in British politics, and departures from it were no longer believed to have grevious economic consequences. The widespread feeling of resignation about adopting protection is nicely captured in a cartoon (reproduced below in figure 1) from Punch in November 1923, just weeks before the election.

Soon after the Conservatives's conference, Baldwin endorsed three principles: (1) a tariff on imports of foreign manufactured goods, (2) tariff preferences for the Commonwealth, and (3) no import duties on wheat or meat. The National Union of Manufactures welcomed Baldwin's proposals and sought to generate public support for a policy of selective protection. According to Snyder (1944, p. 154), this group maintained that 36,043 jobs would be created among its member firms if Baldwin's proposal to protect the home market was implemented. Several 
regional Chambers of Commerce and other industries beset by import competition also lined up behind the Conservatives.

Agriculture was a more sensitive issue. Free traders demolished previous attempts at tariff reforms by stigmatizing any policy with even a remote chance of increasing the price of foodstuffs as the "stomach tax" or the "dear loaf" policy. This played on the fears of the working classes, which found food taxes quite unpalatable. Free-trade Conservatives in Lancashire and Manchester typically found tariff reform proposals hard to swallow for this reason and, recalling previous electoral defeats, were skeptical of Baldwin's enterprise. But Baldwin had specifically avoided pledging tariff protection to agriculture to avoid alienating the labor vote. Yet at the same time, Conservatives in agricultural districts were outraged at their neglect and demanded some form of relief.

In his election address to constituents, Baldwin formally outlined his platform. Imposing duties on imported manufactured goods to aid employment in industry, he argued, would at the same time (1) raise revenue to pay for unemployment relief, (2) protect industries afflicted by unfair foreign competition, (3) help reduce foreign tariffs on British exports through negotiations, (4) establish substantial preferences for the Commonwealth. "It is not our intention, in any circumstance, to impose any duties on wheat, flour, oats, meat (including bacon and ham), cheese, butter, or eggs," Baldwin stated (Craig 1975, p. 46).

In an effort to win rural districts, however, agriculture would be assisted with "a direct measure of support" through "a bounty of $£ 1$ an acre on all holdings of arable land exceeding one acre." Baldwin explained that "the main object of that bounty is to maintain employment on land and so keep up the wages of agricultural labour." This subsidy would promote landed interests 
but not increase the price of food and annoy labor as a tariff would.

Tremendous uncertainty remained about the criteria for determining which industrial and agricultural products would benefit from Baldwin's scheme. Baldwin refused to divulge which manufactures would receive protection. Instead, he asked a select group of tariff reformers to draw up a "secret tariff." The list of "non-essential" foods, which were never completely identified, could be taxed to help establish preferences for the Empire. In one instance, apples were deemed non-essential and could thereby receive protection through tariff preferences, but orchards also counted as arable land and could receive the $£ 1$ per acre subsidy. The following election verse (from Hirst 1927, p. 19) mocks, in Baldwin's voice, some of the confusion surrounding the campaign proposals:

"I'm a plain and simple countryman. This tariff bothers me.

I cannot make my meaning clear for other folks to see.

For instance, when a heckler asks -- and asking seems to scoff --

'Why put a tax on apples and from cider take it off?'

I'm blessed if I can answer, when I'm out in Worcestershire, Where people grow the apples and so want them to be dear.

"My Bewdley Tariff works all right in Bewdley; but we find That every other county seems to need a different kind. Dundonians want free honey, with a tax on marmalades; Brum would prohibit foreign guns, and Sheffield razor blades. The politicians prime me; but their primings disagree.

On one side there is Derby, on the other Amery.

"I try to keep the whole thing vague; but through the screen of smoke A swarm of puzzling questions seem to penetrate and poke. What taxes are protective, and what are preferential? And what are raw materials, and what are foods essential? And then at last a poser comes, perplexing and belated: -'If apples are protected, why are orchards compensated?'

"This is 'the mildewed straw' that breaks my patient camel's back. So send me home to Astley Hall and let me have the sack. Those die-hards put me in this fix, and made me tariff faker. 
Better retire, resume the squire, and earn a pound an acre."

The two main opposition parties, Labour and the Liberals, rejected the turn toward protection, emphatically denying that higher tariffs were a remedy for higher unemployment.

According to Labour's election manifesto:

"The Labour Party challenges the Tariff policy and the whole conception of economic relations underlying it. Tariffs are not a remedy for Unemployment. [Unemployment is a recurrent feature of the existing economic system, common to every industrialised country, irrespective of whether it has Protection or Free Trade.] They are an impediment to the free interchange of goods and services upon which civilized society rests. They foster a spirit of profiteering, materialism and selfishness, poison the life of nations, lead to corruption in politics, promote trusts and monopolies, and impoverish the people. They perpetuate inequalities in the distribution of the world's wealth won by the labour of hands and brain. These inequalities the Labour Party means to remove." [Craig (1975), pp. 478.]

The Liberals once again championed their old cause of free trade:

"Trade restrictions cannot cure unemployment. Post-war conditions do not justify such restrictions; they merely render it more disastrous. High prices and scarcity can only lower the standard of living, reduce the purchasing power of the country, and thereby curtain production. An examination of the figures shows that the suggested tariff cannot possibly assist those trades in which unemployment is most rife. The last thing which taxation on imports can provide is to provide more work for those engaged in manufacture for export." [Craig (1975), p. 51.]

Despite their similar views on trade policy, Labour and the Liberals fought the election separately because they could not agree on other issues, such as remedies for unemployment and the capital levy. Both, however, argued that import tariffs would not reduce unemployment among those in export industries. ${ }^{4}$ They also exploited working class fears by questioning whether the Conservatives could be trusted not to put taxes on food imports.

${ }^{4}$ During the campaign John Maynard Keynes made his famous pronouncement that a tariff to remedy unemployment was "the Protectionist fallacy in its grossest and crudest form." 
Table 1, indicating the international trade position of select industries, provides the first evidence on the possible political economy stances of voters employed in various sectors. ${ }^{5}$ Agriculture, leather, wood, paper, and (to a lesser extent) scientific instruments all appear to face the greatest import competition. Thus, in the case of agriculture, for example, the possibility of subsidies and perhaps even import duties was certain to reinforce the Conservative capture of votes in those districts. Conversely, export industries such as mining, metals, machinery, and textiles might be thought to show broad support for free trade.

Yet the broad sectoral aggregation of these commodities masks a high degree of import penetration in particular segments of an industry. Therefore, this evidence should be supplemented with contemporary observations on the political stance of various groups. Many business groups remained large net exporters and were skeptical of Baldwin's proposals. The National Association of Merchants and Manufactures, the National Chamber of Trade, and the Chamber of Shipping among others all opposed Baldwin.

But even export industries that traditionally supported free trade had reconsidered their position in light of growing import competition. Despite its large net export position, the textile industry was no longer a stronghold of free trade sentiment. In the weeks before the election, parts of the industry (woolens, worsteds, and hosiery) had sought protection under the Safeguarding of Industries Act. The scores of unemployed textile workers in Lancashire and elsewhere, according to Snyder (1944, p. 151), "made it possible for the factory owners, who had swung over in large numbers to the side of protection, to influence their workers." Iron and steel

${ }^{5}$ British trade data are available in greater detail than presented in this table, but are aggregated for comparablility with the production and consumption data from the Census of Production. 
manufacturers consistently sought protection after World War I, arguing that tariffs were necessary prevent the dumping that they claimed imperiled the industry. Representatives of the iron and steel industry contended that protection would not increase prices to users because scale economies could be realized, but those users (such as the shipbuilding industry) were skeptical of such claims. The protectionist case was also championed by new, emerging industries such as automobiles.

The result of the general election (for England alone), held on December 6, 1923, is presented in Table 2. The Conservatives captured virtually the same share of the vote as they had in 1922, losing just 1.7 percentage points. The combined share of Labour and the Liberals rose 3.3 percentage points, mainly at the expense of smaller parties. These slight shifts obscure a dramatic change in parliamentary representation. The Conservatives lost almost 100 seats (and their majority) in parliament, paving the way for the first Labour government headed by J. Ramsay MacDonald. Thus, what needs to be explained is not only the shift in the aggregate support for the three parties, but also the composition of their support across counties.

\section{An Analysis of the 1923 Voting Patterns}

Mayer's (1984) analysis of democratic voting on tariffs points to three consideration -- (1) general equilibrium structure of the economy, (2) distribution of (non-human) factor ownership (such as land and capital), (3) franchise restrictions and voter eligibility -- that should be addressed before analyzing the vote directly. The first issue will be taken up in the context of the econometric results; the second and third deserve immediate consideration. 
The distribution of factor ownership matters in that wages may not be the most important source of income for certain classes of voters. In this case, occupation may be a misleading indicator about where true economic interests lie. In Britain, however, the overwhelming majority of the population were wage earners whose only source of income was from their current occupation. According to the 1921 Census, 90 percent of the occupied population (over 12 years of age) were wage and salary workers (employees), 6 percent self-employed, and 4 percent employers. Furthermore, the distribution of income was severely unequal, indicating a high concentration of land and capital ownership. In 1923, according to Atkinson and Harrison (1978, p. 141), the top 1 percent of the population held 61 percent of the total wealth, the top 5 percent held 82 percent, the top 10 percent held 89 percent, and the top 20 percent held 94 percent.

The Representation of the People Act of 1918 enfranchised all men above the age of 21 and all women above the age of 30. A residency qualification of 6 months affected those who had recently moved between districts, only a small fraction of the electorate. As described below, the census data will be adjusted in an attempt to exclude those not in the electorate.

The econometric approach taken in this paper is similar to that in my paper analyzing the 1906 election: cross-county voting patterns will be related to census data on constituents in each county. The dependent variable is the $\log$ of the odds ratio, $\ln \left[p_{i} /\left(1-p_{i}\right)\right]$, where $p_{i}$ is the proportion of voters in county i who voted for the free trade parties (Labour and the Liberals, which have been combined here). Election data by district from Craig (1969) has been summed to the county level (using Craig 1972) to match the census data.

The independent variables are the occupational or skill characteristics of the constituents in each county taken from the 1921 Census of England. For occupations, the Census Office 
(1923) produced data on the distribution of 32 occupational groups for men and women (aged 12 and higher) in 51 English counties. ${ }^{6}$ To make these data conform more closely to the potential electorate, the sample has been adjusted using census information on the age distribution of each occupational category. The final sample includes the occupations of men aged 20 and higher and women aged 25 and higher. For each occupational category, the Registrar-General (1927) reports the class distribution (skill or income level) within five categories: an upper and middle class, a skilled labor class, an unskilled labor class, and two intermediate categories between them. To calculate the class composition of a district, the skill distribution of each occupational category is assumed to be identical across districts.

Basic features of the data are available in Table 3. The first two columns indicate the overall size and concentration (across counties) of the occupational categories. Large shares of total employment indicate which industries that potentially weigh heavily in the election outcome. Agriculture and mining, for example, account for 14.3 and 3.8 percent of the electorate sample, respectively. Although the tariff debate concentrated on the manufacturing sector (21.4 percent of the electorate sample), their views could be overwhelmed by those employed in the service sector (comprising 60.5 percent of the sample). Concentration is important in that the outcome in certain counties may hinge on groups whose overall size may be small but which are clustered in one region. Mining, metals, and textiles are concentrated in this way. The last five columns indicate the distribution of skills or economic class in each occupational category as determined

${ }^{6}$ The sample has been confined to England alone, which accounted for 82 percent of the votes cast. Wales was uniformly in favor of Labour and the Liberals (in this and in the 1922 election) with several uncontested seats. Scotland conducted a separate census with different census categories. 
by the Registrar-General.

The fact that these data are based on an occupational rather than an industrial classification creates a problem. Because laborers, stationary engineers, clerks, and others are not given an industrial affiliation even though they worked for a specific industry, the interest of these workers in promoting the industry in which they were employed will be missed. Fortunately, this concern applies to just a few of the available occupational categories in the service sector. The deficiency is mitigated to the extent that these workers had general rather than industry-specific skills. In this case, they might be more mobile than others; for example, a clerk employed by the textile industry might have less of a stake in that industry than a textile worker.

The following equation, relating the county vote to characteristics of the electorate in that county, is estimated by weighted least squares to account for the unequal size of each county and to correct for heteroskedasticity: ${ }^{7}$

$$
\ln \left[p_{i} /\left(1-p_{i}\right)\right]=\alpha+\sum_{j=1}^{n} \beta_{j} \ln \left(X_{j i}\right)+\varepsilon_{i}
$$

where $p_{i}$ is the proportion of vote in county $i$ for the free trade Labour and Liberal parties, $X_{j i}$ is the proportion of occupation or class $j$ in county $i$, and $\varepsilon_{i}$ is the error term.

The first set of results is reported on Table 4. In this table, broad sectoral aggregates are constructed from the occupational data. In the first specification, the log of the odds ratio is regressed on the four sectoral aggregates (agriculture, mining, manufacturing, and services). The results indicate that all sectors but mining are strongly negatively correlated with voting for the free trade parties. Because a large component of support for free trade is captured by the

The weights are equal to $w_{i}=\left\{p_{i} / n_{i}\left(1-p_{i}\right)\right\}^{1 / 2}$, where $n_{i}$ is the total vote count in each county. 
constant terms, these results are largely uninformative.

The second and third specifications analyze the change or the "swing" in the 1923 election patterns from those in the previous (1922) election. The second specification includes the lagged value of the $\log$ of the odds ratio from the 1922 election, while in the third the dependent variable is the difference in the log of the odds ratios. These specifications may be informative for the following reason: while there is substantial persistence in both regional voting trends and regional employment composition, voting patterns can be expected to shift at the margin as economic interests (which were not as important in previous elections) replace other considerations in affecting voter behavior.

Three patterns emerge from these regressions: (1) counties with employment concentration in agriculture and manufacturing swung toward the Conservative party in the 1923 election compared with the prior election, (2) counties heavily populated with those employed in mining did not swing toward the Liberals or Labour, primarily because those counties were already overwhelming represented in parliament by those parties, and (3) the net contribution by service employment is ambiguous. Although the estimate in the last equation is imprecise, the coefficient on services is positive and, given the overwhelming share of the electorate in this category, might account for the election outcome in this specification.

Table 5 analyzes the county vote pattern by economic class. The only information that can be gleaned from the first specification is that counties with a concentration of upper and middle income voters tended to vote Conservative, but this does not carry over to the other specifications that control for the prior voting pattern. If class considerations were important in determining the election outcome, one would expect to see a positive coefficient on unskilled 
labor, but this is not apparent. The first specification is also the best test of the class hypothesis since other specifications that control for past voting behavior would also be dominated by class considerations. Yet this table is completely uninformative about the determinants of the 1923 election or why the results differed from the previous election. One is tempted to draw the conclusion that skill levels and income classes are not good explanatory variables for the voting patterns in the 1923 election. However, this conclusion must be tempered by the recognition that problems may exist with the original social grading of occupational categories as undertaken by the Registrar-General or with the assumption that the within-occupation distribution of class is the same across counties

Table 6 breaks down the vote by occupational category, including only those (14) groups in traded goods industries. Focussing on the third specification, we find that regressors explain 26 percent of the variation in the difference of the log of the odds ratio, much more than previous regressions were able to and adjusting for the different number of regressors which the occupational data allow. Counties with occupational concentrations in agriculture, metals, and textile workers appear to have swung toward the Conservatives compared to the previous election; coefficients on these variables are also statistically significant and are in line with the discussion in the previous section. Those working with mine products supported free trade, although this pattern in not so evident among mine workers themselves. In earlier specifications at least, counties with concentrations of those working on textile products were correlated with votes for the free trade parties. Thus, in both textiles and mining, there is slight evidence of the following divergence in economic interests: namely, downstream-user industries favor free trade to acquire their inputs from the source at the lowest possible cost, while upstream producers 
(even if net exporters) may be facing some import competition and would desire tariff protection.

As in the 1906 general election results, the constant terms also weighs in positively and significantly, indicating broader support for the free trade parties than is captured by these occupational categories. A plausible interpretation for this result is that many voters in service sectors, which are relatively uniformly distributed across England, voted against protection to keep the price of their inputs or consumption articles inexpensive. This hypothesis is explored further in Table 7, which includes occupational categories from the non-traded goods sector (services). While these results are less informative than those in Table 6, one result remains pronounced: the swing of textiles workers toward the Conservatives. None of the standard accounts of professionals in the City of London and elsewhere supporting free trade is evident, although clerks do seem to be related to voting for free trade.

A formal test to discriminate between the two competing models -- class versus occupational voting -- confirms what one already suspects from the results, namely that the occupational regressors (in traded goods industries) explain the election outcome better than the class regressors in choosing between the third specifications in Tables 5 and 6 . Davidson and MacKinnon's (1981) $\mathrm{J}$ test allows us to assess $\mathrm{H}_{0}$ (the occupational model is appropriate) against $\mathrm{H}_{1}$ (the class/skill model is appropriate) by an indirect linear combination of the two models (with $\alpha$ the weight on the second model). In the first case, we cannot reject the hypothesis that $\mathrm{H}_{0}$ is true because including the fitted values from the class model enter with $\hat{\alpha}=0.87$ with a $t$ ratio of 1.07. This does not preclude the possibility that we also cannot reject $H_{1}$. Reversing the test, however, we can reject $H_{1}$ because $\hat{\alpha}=6.98$ with a $t$ ratio of 6.07 . Thus, the occupation model 
dominates the class model. ${ }^{8}$

These results conform to our current understanding of labor markets in interwar Britain.

Thomas (1992) argues that insider-outsider models of unemployment fit the British experience of the 1920 s and 1930 s well. As he notes:

"Those workers who lost jobs in the traditional staple industries (coal, shipbuilding, iron and steel, textiles), especially those with well-developed, industry specific skills, took on the character of outsiders to the vibrant sectors of the labour market, such as services, light engineering, and vehicles. It is no accident that most of the long-term unemployed (57\% in 1936) came from the staple sectors. These workers were unlikely to find work in either their own trades or elsewhere. They had very low reemployment probabilities from the very moment of dismissal, joining an extremely long queue at the exchanges, made up of individuals with distressingly similar career histories" [Thomas (1992), p. 300].

This description and the empirical results presented above are consistent with the political divisions suggested by the imperfect labor mobility variant of the specific factor model, as developed by Mussa (1982) and Baldwin (1984). There is less support for the notion that distinct class differences were driving voting patterns, at least in this election where the outcome would directly affect important economic interests.

Were occupational characteristics decisive in determining the election outcome for many counties? We can answer this question from the second specification in Table 6 by calculating $\hat{p}_{i}$ $\bar{p}_{i}$, the predicted value of $p_{i}$ minus the predicted mean value of $p$ (as when the county had sampleaverage occupational characteristics). This measures the portion of the county's vote that can be attributed to the particular distribution of occupations there. After computing $y=p_{i}-\left(\hat{p}_{i}-\bar{p}_{i}\right)$, where $p_{i}$ is the actual percentage Liberal-Labour vote in the county, if either $p_{i}>0.5$ and $y<0.5$,

${ }^{8}$ While the occupational voting regressions have many more independent variables, the class voting regressions have fewer "grouped" variables which also tends to increase the goodness of fit. 
or $p_{i}<0.5$ and $y>0.5$, then occupational factors were decisive in shifting the election outcome in that country. ${ }^{9}$

Of the 51 counties in the sample, occupational voting patterns proved decisive in 13 counties ( 25 percent). This calculation tells more about the sources of support for the Conservatives than for the Labour or Liberal parties because deviations must be made from $\bar{p}_{i}$, the average level of support for the Labour and the Liberals. In 10 of the 13 cases, the particular configuration of occupations shifted the vote to the Conservatives. The Conservatives dropped from having majorities in 25 to 12 counties after the two elections, a decline of 13 of which 3 can be attributed to specific occupational concentrations. This is not to say that industry or occupational considerations were not important in other counties, but these results cannot be distinguished from those in counties having sample average characteristics.

\section{Conclusions and Speculations}

This paper has provided additional evidence for viewing the political economy of trade policy through the lens of the Mussa (1982) and Baldwin (1984) models of imperfect factor mobility. Even in an economy noted for its class stratification, such class sentiments were not sufficient to overcome strong, underlying economic interests when those interests were at stake. This paper has not made any direct test of those models or any direct test of factor mobility itself. Rather, in terms of observable political behavior, however determined, the specific-factors type

9 This is a stringent standard. For example, if $p_{i}=\hat{p}_{i}=0.60$ and $\bar{p}_{i}=0.55$, then even though the model accounts for the actual vote in the county, the occupational patterns there were not sufficiently different from an average county to change whether it would have voted Liberal or not. On the other hand, if $p_{i}=\hat{p}_{i}=0.48$, and $\bar{p}_{i}=0.55$, then the concentration of occupations in the county was sufficient to swing it from voting Liberal or Labour to voting Conservative. 
models conform better to the evidence than those making strong factor mobility assumptions

In defense of the political economy implications of the Heckscher-Ohlin model with perfect factor mobility, some economists argue that the short-term interests of factors will dominate longer term interests if policy decisions are viewed as short-term or are easily reversed. This ignores the point that policy reversals are costly; witness the fact that, within five years the repeal of the highly controversial Corn Laws, it was accepted as a policy decision with no further attempt to overturn it.

The failure of the protectionist "Tariff Reformers" in the first quarter of this century in Britain was also not independent of the institutional mechanism by which decisions about commercial policy were made. Since the costs of voting are arguably lower than the costs of lobbying, the free-rider problems often said to afflict dispersed free-trade interests are absent in direct voting. Democratic voting thereby affects the configuration of interests that are represented in the political arena, which in turn affects the political outcome. In the British case, the electorate repeatedly established (in the 1906, 1910, and 1923 elections) the equilibrium political outcome as free trade. When higher tariffs were finally introduced during the Great Depression, they came not as a result of such an election, but through a legislative vote in a Conservative-dominated parliament. ${ }^{10}$ Why Conservative parliaments did not simply enact such legislation earlier without seeking an electoral mandate, of course, is a story for another paper.

10 As there was, strictly speaking, a National Government, the Tories could delude themselves and the electorate that this was a National and not a party decision. 
Figure 1

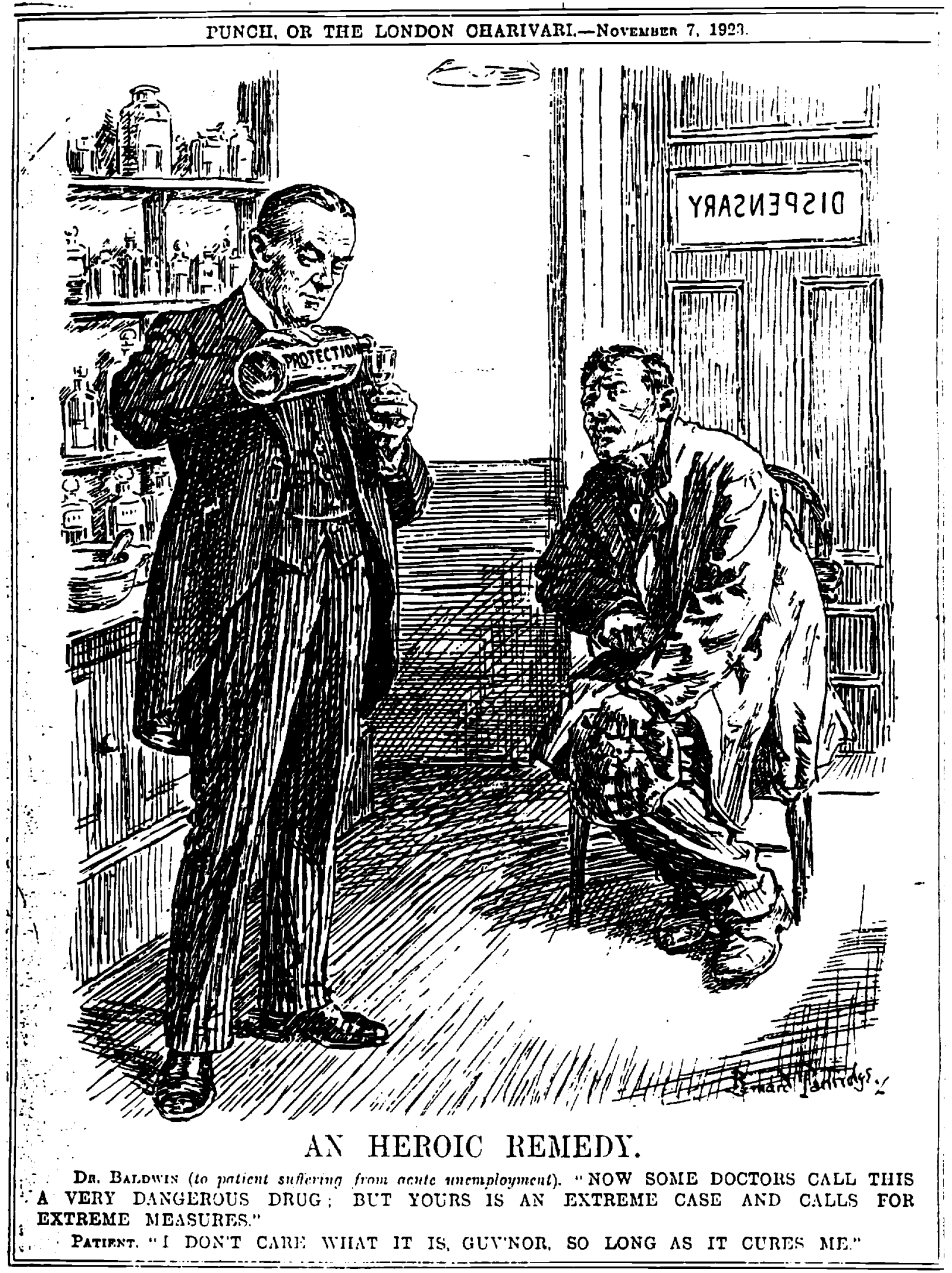


Table 1

Industry Position in International Trade, 1924

(figures in millions $\mathfrak{\mathfrak { f }}$ )

$\begin{array}{llll}\text { Gross } & \text { Exports/ } & \text { Imports/ } & \text { Trade } \\ \text { Output } & \text { Production } & \text { Consumption } & \text { Balance }\end{array}$

$\begin{array}{lcccc}\text { Agriculture } & 779.2 & 5.7 & 40.9 & -464.5 \\ \text { Mining } & 274.7 & 37.9 & 13.1 & 78.5 \\ \text { Bricks, etc. } & 75.7 & 16.2 & 10.7 & 4.8 \\ \text { Chemicals } & 142.4 & 18.0 & 10.3 & 12.2 \\ \text { Metals } & 499.4 & 23.5 & 11.0 & 70.5 \\ \text { Electrical } & 74.5 & 13.7 & 3.6 & 7.8 \\ \text { Scientific Instruments } & 62.3 & 11.9 & 11.4 & 0.3 \\ \text { Machinery } & 156.2 & 28.5 & 7.7 & 35.2 \\ \text { Leather } & 54.7 & 10.5 & 19.6 & -6.1 \\ \text { Textiles } & 992.5 & 27.1 & 9.3 & 194.3 \\ \text { Wood } & 82.3 & 2.3 & 5.4 & -2.7 \\ \text { Paper } & 170.4 & 5.1 & 7.8 & -4.8\end{array}$

Sources: Final Report on the Third Census of Production of the United Kingdom [1924] (1930). Customs and Excise Office (1924) 
23

Table 2

General Election Results, 1922 and 1923

(England Only)

\begin{tabular}{||l|c|c||}
\hline & $\begin{array}{c}\text { Share of 1922 Vote } \\
\text { (MPs Elected) }\end{array}$ & $\begin{array}{c}\text { Share of 1923 } \\
\text { Vote } \\
\text { (MPs Elected) }\end{array}$ \\
\hline Conservative & $\begin{array}{c}41.5 \\
(336)\end{array}$ & $\begin{array}{c}39.8 \\
(245)\end{array}$ \\
\hline Liberal & 26.9 & 29.6 \\
$(80)$ & $(126)$ \\
\hline Labour & $\begin{array}{l}28.8 \\
(97)\end{array}$ & $\begin{array}{c}29.7 \\
(139)\end{array}$ \\
\hline Other & 2.8 & $\begin{array}{l}0.6 \\
(4)\end{array}$ \\
\hline Total & $(9)$ & 100.0 \\
& $(514)$ & $(522)$ \\
\hline
\end{tabular}

Source: Craig (197I), pp. 3-5. 
Table 3

Census Data on Occupations in England, 1921

Fishermen

Agriculture

Mining

Mine Products

Brick, Pottery, etc

Chemicals

Metal Workers

Electroplate/Precious Metals

Electrical

Scientific Instruments

Leather Goods

Textile Workers

Textile Products

Makers of Food, etc

Wood and Furniture

Paper and Printers

Builders

Painters

Workers in Other Materials

Workers in Mixed Materials

Gas, Water, Electric Workers

Transport \& Communications

Commerce, Finance, Insurance

Government \& Defense

Professionals

Entertainment

Personal Service

Clerks

Warehousemen, Storekeepers

Stationary Engine Drivers

Other Workers (Laborers)

Unoccupied and Retired

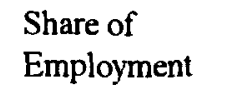

Concentration"

$$
0.3
$$

14.0

3.6

0.2

0.6

0.3

7.1

0.1

0.6

0.1

0.3

2.1

4.4

1.7

3.0

1.1

3.5

1.2

0.2

0.5

0.2

7.2

8.0

3.0

5.1

0.5

13.8

2.8

0.8

0.7

4.9

8.1
12.0

3.0

8.0

4.7

9.2

5.0

2.7

35.1

2.5

3.0

3.4

9.9

4.2

2.7

2.2

2.7

2.0

2.2

6.0

2.9

2.1

2.1

2.0

3.4

2.1

3.0

2.2

2.4

2.6

2.7

2.0
Skill Level

I II III IV $\mathrm{V}$

$\begin{array}{lllll}0.00 & 0.00 & 0.00 & 1.00 & 0.00\end{array}$

$\begin{array}{lllll}0.00 & 0.30 & 0.21 & 0.46 & 0.02\end{array}$

$\begin{array}{lllll}0.00 & 0.01 & 0.62 & 0.36 & 0.01\end{array}$

$\begin{array}{lllll}0.00 & 0.05 & 0.06 & 0.23 & 0.66\end{array}$

$\begin{array}{lllll}0.00 & 0.06 & 0.64 & 0.08 & 0.21\end{array}$

$\begin{array}{lllll}0.00 & 0.11 & 0.44 & 0.45 & 0.00\end{array}$

$\begin{array}{lllll}0.00 & 0.04 & 0.74 & 0.22 & 0.00\end{array}$

$\begin{array}{lllll}0.00 & 0.14 & 0.85 & 0.01 & 0.00\end{array}$

$\begin{array}{lllll}0.00 & 0.05 & 0.85 & 0.10 & 0.00\end{array}$

$\begin{array}{lllll}0.00 & 0.10 & 0.90 & 0.00 & 0.00\end{array}$

$\begin{array}{lllll}0.00 & 0.12 & 0.79 & 0.09 & 0.00\end{array}$

$\begin{array}{lllll}0.00 & 0.07 & 0.76 & 0.17 & 0.00\end{array}$

$\begin{array}{lllll}0.00 & 0.18 & 0.77 & 0.05 & 0.00\end{array}$

$\begin{array}{lllll}0.00 & 0.18 & 0.56 & 0.26 & 0.00\end{array}$

$\begin{array}{lllll}0.00 & 0.05 & 0.78 & 0.11 & 0.06\end{array}$

$\begin{array}{lllll}0.00 & 0.11 & 0.78 & 0.08 & 0.03\end{array}$

$\begin{array}{lllll}0.00 & 0.11 & 0.35 & 0.14 & 0.40\end{array}$

$\begin{array}{lllll}0.00 & 0.06 & 0.88 & 0.00 & 0.06\end{array}$

$\begin{array}{lllll}0.00 & 0.05 & 0.80 & 0.15 & 0.00\end{array}$

$\begin{array}{lllll}0.00 & 0.09 & 0.84 & 0.02 & 0.05\end{array}$

$\begin{array}{lllll}0.06 & 0.05 & 0.16 & 0.40 & 0.33\end{array}$

$\begin{array}{lllll}0.01 & 0.08 & 0.44 & 0.34 & 0.13\end{array}$

$\begin{array}{lllll}0.12 & 0.57 & 0.27 & 0.00 & 0.04\end{array}$

$\begin{array}{lllll}0.05 & 0.46 & 0.37 & 0.12 & 0.00\end{array}$

$\begin{array}{lllll}0.55 & 0.38 & 0.07 & 0.00 & 0.00\end{array}$

$\begin{array}{lllll}0.00 & 0.13 & 0.81 & 0.06 & 0.00\end{array}$

$\begin{array}{lllll}0.00 & 0.32 & 0.56 & 0.12 & 0.00\end{array}$

$\begin{array}{lllll}0.04 & 0.96 & 0.00 & 0.00 & 0.00\end{array}$

$\begin{array}{lllll}0.00 & 0.00 & 0.66 & 0.34 & 0.00\end{array}$

$\begin{array}{lllll}0.00 & 0.00 & 0.52 & 0.48 & 0.00\end{array}$

$\begin{array}{lllll}0.00 & 0.03 & 0.08 & 0.89 & 0.00\end{array}$ 
Definition of Skill Level: 1 - Upper and Middle, II - Intermediate, III - Skilled, IV - Intermediate, V - Unskilled.

- Herfindahl index of geographic concentration is $100 \times \sum \mathbf{s}_{\mathrm{i}}$, where $\mathrm{s}_{\mathrm{i}}$ is the share of an employment category in district i.

Source: Census Office (1923); Registrar-General (1927), pp. ciii-cxiv. 
Table 4

Sectoral Voting

\begin{tabular}{||l|c|c|c||}
\hline $\begin{array}{l}\text { Sector } \\
\text { (Share of Employment) }\end{array}$ & $\ln \left[\mathrm{p}_{i} /\left(1-\mathrm{p}_{\mathrm{i}}\right)\right]$ & $\ln \left[\mathrm{p}_{\mathrm{i}} /\left(1-\mathrm{p}_{\mathrm{i}}\right)\right]$ & $\Delta \ln \left[\mathrm{p}_{\mathrm{i}} /\left(1-\mathrm{p}_{\mathrm{i}}\right)\right]$ \\
\hline Constant & 9.08 & 3.26 & -0.25 \\
& $(2.45)$ & $(1.69)$ & $(0.12)$ \\
\hline Agriculture & -0.21 & -0.13 & -0.09 \\
$(14.3)$ & $(5.67)$ & $(4.70)$ & $(2.88)$ \\
\hline Mining & 0.01 & 0.01 & 0.01 \\
$(3.8)$ & $(0.22)$ & $(0.45)$ & $(0.46)$ \\
\hline Manufacturing & -0.19 & -0.21 & -0.22 \\
$(22.4)$ & $(1.71)$ & $(2.67)$ & $(2.42)$ \\
\hline Services & -1.23 & -0.25 & 0.32 \\
(59.5) & $(3.34)$ & $(0.87)$ & $(1.08)$ \\
\hline Lagged Log of Odds & -- & 0.62 & - \\
Ratio & & $(6.81)$ & 0.03 \\
\hline Unweighted R2 & 0.49 & 0.70 & 12.8 \\
\hline F & 43.3 & 79.1 & 0.23 \\
\hline unweighted s.e. & 0.24 & 0.18 & \\
\hline
\end{tabular}

Note: $\mathrm{t}$ statistics in parenthesis. 
Table 5

Class Voting

\begin{tabular}{||l|c|c|c|}
\hline & $\ln \left[\mathrm{p}_{1} /\left(1-\mathrm{p}_{\mathrm{j}}\right)\right]$ & $\ln \left[\mathrm{p}_{1} /\left(1-\mathrm{p}_{\mathrm{j}}\right)\right]$ & $\Delta \ln \left[\mathrm{p}_{\mathrm{i}} /\left(1-\mathrm{p}_{\mathrm{j}}\right)\right]$ \\
\hline Constant & 7.30 & 2.81 & 0.73 \\
& $(1.21)$ & $(0.61)$ & $(0.15)$ \\
\hline (I) Upper and Middle & -1.77 & -0.40 & 0.23 \\
& $(2.74)$ & $(0.74)$ & $(0.45)$ \\
\hline (II) Intermediate & 0.53 & 0.20 & 0.05 \\
& $(0.77)$ & $(0.38)$ & $(0.08)$ \\
\hline (III) Skilled Labor & 0.07 & -0.04 & -0.08 \\
& $(0.15)$ & $(0.11)$ & $(0.24)$ \\
\hline (IV) Intermediate & -0.66 & -0.37 & -0.23 \\
& $(1.23)$ & $(0.95)$ & $(0.57)$ \\
\hline (V) Unskilled Labor & -0.28 & -0.07 & 0.02 \\
& $(0.73)$ & $(0.26)$ & $(0.06)$ \\
\hline Lagged Log of Odds & -- & 0.68 &.- \\
& & $(6.03)$ & .03 \\
\hline Unweighted R & .32 & .62 & 6.1 \\
\hline F & 23.2 & 41.1 & 0.25 \\
\hline unweighted s.e. & 0.39 & 0.21 & \\
\hline
\end{tabular}

Note: $\mathbf{t}$ statistics in parenthesis. 
Table 6

\section{Occupation Voting}

(traded goods industries)

\begin{tabular}{|c|c|c|c|}
\hline & $\ln \left[p_{i} /\left(1-p_{i}\right)\right]$ & $\ln \left[\mathrm{p}_{\mathrm{j}} /\left(1-\mathrm{p}_{\mathrm{i}}\right)\right]$ & $\Delta \ln \left[p_{i} /\left(1-p_{i}\right)\right]$ \\
\hline \multirow[t]{2}{*}{ Constant } & 1.37 & 1.58 & 1.69 \\
\hline & $(1.56)$ & $(2.93)$ & $(2.57)$ \\
\hline \multirow[t]{2}{*}{ Agriculture } & -0.22 & -0.14 & -0.01 \\
\hline & $(3.96)$ & $(3.76)$ & $(2.10)$ \\
\hline \multirow[t]{2}{*}{ Mine Workers } & 0.01 & -0.01 & -0.02 \\
\hline & $(0.50)$ & $(0.65)$ & $(1.21)$ \\
\hline \multirow[t]{2}{*}{ Mine Products } & -0.01 & -0.01 & 0.03 \\
\hline & $(0.40)$ & $(1.24)$ & $(1.90)$ \\
\hline \multirow[t]{2}{*}{ Bricks } & -0.03 & -0.03 & -0.03 \\
\hline & $(0.55)$ & $(0.86)$ & $(0.69)$ \\
\hline \multirow[t]{2}{*}{ Chemicals } & 0.02 & 0.00 & -0.01 \\
\hline & $(0.82)$ & $(0.08)$ & $(0.51)$ \\
\hline \multirow[t]{2}{*}{ Metals } & 0.25 & -0.03 & -0.18 \\
\hline & $(1.69)$ & $(0.26)$ & $(1.62)$ \\
\hline \multirow[t]{2}{*}{ Electrical } & -0.40 & -0.06 & 0.13 \\
\hline & $(2.43)$ & $(0.52)$ & $(1.07)$ \\
\hline \multirow[t]{2}{*}{ Scientific } & -0.06 & -0.09 & -0.10 \\
\hline & $(0.55)$ & $(1.27)$ & $(1.20)$ \\
\hline \multirow[t]{2}{*}{ Leather } & -0.19 & -0.05 & 0.03 \\
\hline & $(2.19)$ & $(0.91)$ & $(0.39)$ \\
\hline \multirow[t]{2}{*}{ Textile Workers } & -0.01 & -0.02 & -0.03 \\
\hline & $(0.28)$ & $(2.00)$ & $(2.38)$ \\
\hline \multirow[t]{2}{*}{ Textile Products } & 0.24 & 0.07 & -0.02 \\
\hline & $(2.12)$ & $(1.00)$ & $(0.24)$ \\
\hline \multirow[t]{2}{*}{ Food } & -0.11 & 0.01 & 0.08 \\
\hline & $(0.75)$ & $(0.10)$ & $(0.69)$ \\
\hline
\end{tabular}


29

\begin{tabular}{||l|c|c|c||}
\hline Wood & $\begin{array}{c}-0.42 \\
(1.32)\end{array}$ & $\begin{array}{c}-0.26 \\
(1.32)\end{array}$ & $\begin{array}{c}-0.17 \\
(0.71)\end{array}$ \\
\hline Paper & 0.11 & -0.02 & -0.09 \\
& $(0.66)$ & $(0.18)$ & $(0.72)$ \\
\hline Lagged Log of Odds & -- & 0.64 & - \\
Ratio & & $(7.72)$ & 0.26 \\
\hline Unweighted R & 0.58 & 0.81 & 5.2 \\
\hline F & 12.0 & 33.9 & 0.25 \\
\hline unweighted s.e. & 0.26 & 0.18 & \\
\hline
\end{tabular}

Note: $\mathfrak{t}$ statistics in parenthesis. 
Table 7

\section{Occupation Voting}

(traded and nontraded goods industries)

\begin{tabular}{|c|c|c|c|}
\hline & $\ln \left[\mathrm{p}_{/} /\left(1-\mathrm{p}_{\mathrm{i}}\right)\right]$ & $\ln \left[\mathrm{p}_{\mathrm{p}} /\left(1-\mathrm{p}_{i}\right)\right]$ & $\Delta \ln \left[p_{i} /\left(1-p_{i}\right)\right]$ \\
\hline Constant & $\begin{array}{c}2.63 \\
(1.17) \\
\end{array}$ & $\begin{array}{r}0.21 \\
(0.11) \\
\end{array}$ & $\begin{array}{r}-3.67 \\
(1.31)\end{array}$ \\
\hline Agriculture & $\begin{array}{r}-0.21 \\
(3.53) \\
\end{array}$ & $\begin{array}{r}-0.18 \\
(3.43)\end{array}$ & $\begin{array}{c}-0.11 \\
(1.44)\end{array}$ \\
\hline Mine Workers & $\begin{array}{l}-0.00 \\
(0.21)\end{array}$ & $\begin{array}{l}-0.00 \\
(0.11)\end{array}$ & $\begin{array}{c}0.00 \\
(0.09)\end{array}$ \\
\hline Mine Products & $\begin{array}{r}-0.02 \\
(1.28)\end{array}$ & $\begin{array}{l}-0.00 \\
(0.18)\end{array}$ & $\begin{array}{c}0.02 \\
(1.31)\end{array}$ \\
\hline Bricks & $\begin{array}{l}-0.02 \\
(0.60)\end{array}$ & $\begin{array}{l}-0.01 \\
(0.35)\end{array}$ & $\begin{array}{c}0.08 \\
(0.16) \\
\end{array}$ \\
\hline Chemicals & $\begin{array}{r}0.02 \\
(1.04) \\
\end{array}$ & $\begin{array}{r}0.00 \\
(0.27) \\
\end{array}$ & $\begin{array}{r}-0.02 \\
(0.86) \\
\end{array}$ \\
\hline Metals & $\begin{array}{r}0.00 \\
(0.04) \\
\end{array}$ & $\begin{array}{l}-0.03 \\
(0.27) \\
\end{array}$ & $\begin{array}{r}-0.08 \\
(0.50) \\
\end{array}$ \\
\hline Electrical & $\begin{array}{c}0.06 \\
(0.30)\end{array}$ & $\begin{array}{l}-0.05 \\
(0.32)\end{array}$ & $\begin{array}{c}0.04 \\
(0.17)\end{array}$ \\
\hline Scientific & $\begin{array}{l}-0.23 \\
(2.32) \\
\end{array}$ & $\begin{array}{l}-0.19 \\
(2.37)\end{array}$ & $\begin{array}{r}-0.14 \\
(1.09)\end{array}$ \\
\hline Leather & $\begin{array}{l}-0.12 \\
(1.96) \\
\end{array}$ & $\begin{array}{r}-0.06 \\
(1.16) \\
\end{array}$ & $\begin{array}{r}0.03 \\
(0.43) \\
\end{array}$ \\
\hline Textile Workers & $\begin{array}{r}-0.06 \\
(3.15)\end{array}$ & $\begin{array}{r}-0.05 \\
(3.67) \\
\end{array}$ & $\begin{array}{l}-0.05 \\
(2.21) \\
\end{array}$ \\
\hline Textile Products & $\begin{array}{r}0.07 \\
(0.64) \\
\end{array}$ & $\begin{array}{r}0.05 \\
(0.57) \\
\end{array}$ & $\begin{array}{c}0.02 \\
(0.16) \\
\end{array}$ \\
\hline Food & $\begin{array}{c}0.24 \\
(1.68)\end{array}$ & $\begin{array}{r}0.16 \\
(1.37) \\
\end{array}$ & $\begin{array}{r}0.04 \\
(0.20) \\
\end{array}$ \\
\hline
\end{tabular}


31

\begin{tabular}{|c|c|c|c|}
\hline Wood & $\begin{array}{l}-0.06 \\
(0.22) \\
\end{array}$ & $\begin{array}{l}-0.02 \\
(0.11) \\
\end{array}$ & $\begin{array}{r}0.03 \\
(0.09) \\
\end{array}$ \\
\hline Paper & $\begin{array}{r}0.11 \\
(0.98) \\
\end{array}$ & $\begin{array}{r}0.02 \\
(0.30) \\
\end{array}$ & $\begin{array}{l}-0.10 \\
(0.72) \\
\end{array}$ \\
\hline Building & $\begin{array}{r}1.02 \\
(2.81) \\
\end{array}$ & $\begin{array}{r}0.76 \\
(2.48) \\
\end{array}$ & $\begin{array}{r}0.33 \\
(0.73) \\
\end{array}$ \\
\hline Painters & $\begin{array}{l}-0.92 \\
(3.37) \\
\end{array}$ & $\begin{array}{l}-0.64 \\
(2.71) \\
\end{array}$ & $\begin{array}{l}-0.18 \\
(0.55) \\
\end{array}$ \\
\hline Gas, Water, Elec. & $\begin{array}{r}0.22 \\
(1.16) \\
\end{array}$ & $\begin{array}{r}0.15 \\
(1.00) \\
\end{array}$ & $\begin{array}{r}0.05 \\
(0.22) \\
\end{array}$ \\
\hline $\begin{array}{l}\text { Transport \& } \\
\text { Communications }\end{array}$ & $\begin{array}{r}0.05 \\
(0.17) \\
\end{array}$ & $\begin{array}{r}0.09 \\
(0.45) \\
\end{array}$ & $\begin{array}{r}0.17 \\
(0.54) \\
\end{array}$ \\
\hline $\begin{array}{l}\text { Commerce, Finance, } \\
\text { lnsurance }\end{array}$ & $\begin{array}{r}-0.36 \\
(0.82) \\
\end{array}$ & $\begin{array}{r}0.01 \\
(0.03) \\
\end{array}$ & $\begin{array}{c}0.61 \\
(1.11) \\
\end{array}$ \\
\hline Government \& Defense & $\begin{array}{l}-0.05 \\
(0.57) \\
\end{array}$ & $\begin{array}{l}-0.06 \\
(0.08) \\
\end{array}$ & $\begin{array}{l}-0.07 \\
(0.66) \\
\end{array}$ \\
\hline Professionals & $\begin{array}{r}-0.49 \\
(1.27) \\
\end{array}$ & $\begin{array}{l}-0.18 \\
(0.53) \\
\end{array}$ & $\begin{array}{r}0.33 \\
(0.68) \\
\end{array}$ \\
\hline Entertainment & $\begin{array}{r}0.25 \\
(1.70) \\
\end{array}$ & $\begin{array}{r}0.19 \\
(1.61) \\
\end{array}$ & $\begin{array}{r}0.10 \\
(0.58) \\
\end{array}$ \\
\hline Clerks & $\begin{array}{r}0.39 \\
(2.49) \\
\end{array}$ & $\begin{array}{r}0.25 \\
(1.91) \\
\end{array}$ & $\begin{array}{r}0.04 \\
(0.19) \\
\end{array}$ \\
\hline Laborers & $\begin{array}{r}-0.57 \\
(2.07) \\
\end{array}$ & $\begin{array}{r}-0.39 \\
(1.70) \\
\end{array}$ & $\begin{array}{l}-0.10 \\
(0.30) \\
\end{array}$ \\
\hline $\begin{array}{l}\text { Lagged Log of Odds } \\
\text { Ratio }\end{array}$ & -. & $\begin{array}{r}0.38 \\
(3.67) \\
\end{array}$ & -. \\
\hline Unweighted $\mathrm{R}^{2}$ & 0.72 & 0.82 & 0.32 \\
\hline $\mathrm{F}$ & 20.7 & 30.3 & 3.1 \\
\hline unweighted s.e. & 0.25 & 0.14 & 0.28 \\
\hline
\end{tabular}

Note: $t$ statistics in parenthesis 


\section{References}

Alt, James E., and Michael Gilligan. "The Political Economy of Trading States: Factor Specificity, Collective Action Problems and Domestic Political Institutions." Lournal of Political Philosophy 2 (1994): 165-192.

Atkinson, A. B., and Harrison, A. J. Distribution of Personal Wealth in Britain. Cambridge: Cambridge University Press, 1978.

Baldwin, Robert. "Rent Seeking and Trade Policy: An Industry Approach." Weltwirtschlaftliches Archiv 129 (1984): 662-677.

Bhagwati, Jagdish, and Douglas Irwin. "The Return of the Reciprocitarians: U.S. Trade Policy Today." The World Economy 10 (June 1987): 109-130.

Capie, Forrest. Depression and Protection: Britain Between the Wars. London: George Allen \& Unwin, 1983.

Census Office. Census of England and Wales, 1921. General Report. London: His Majesty's Stationery Office, 1923.

Craig, F. W. S. (ed.). British Parliamentary Election Results, 1918-1949. Glasgow: Political Reference Publications, 1969

Craig, F. W. S. (ed.). British Parliamentary Election Statistics. 2nd ed. Chichester: Political Reference Publications, 1971.

Craig, F. W. S. (ed.). Boundaries of Parliamentary Constituencies, 1885-1972. Chichester: Political Reference Publications, 1972.

Craig, F. W. S. (ed.). British General Election Manifestos, 1900-1974. London: Macmillan Press, 1975.

Customs and Excise Office. Annual Statement of the Trade of the United Kingdom, 1923. Vol. 1. London: His Majesty's Stationery Office, 1924.

Davidson, Russell and James G. MacKinnon. "Several Tests for Model Specification in the Presence of Alternative Hypotheses." Econometrica 49 (May 1981): 781-793

Final Report on the Third Census of Production of the United Kingdom (1924). London: His Majesty's Stationery Office, 1930-32.

Hirst, Francis W. Safeguarding and Protection in Great Britain and the United States. New York: Macmillan, 1927. 
Irwin, Douglas A. "The Political Economy of Free Trade: Voting in the British General Election of 1906." Lournal of Law and Economics 37 (April 1994): 75-108.

Magee, Stephen P. "Three Simple Tests of the Stolper-Samuelson Theorem." In Peter Oppenheimer (ed.), Issues in International Economics. Stockfield, England: Oriel Press, 1978.

Mayer, Wolfgang. "Endogenous Tariff Formation." American Economic Review 74 (December 1984): $970-985$.

Ministry of Labour. 18th Abstract of Labour Statistics of the United Kingdom. London: His Majesty's Stationery Office, 1926.

Mussa, Michael. "Imperfect Factor Mobility and the Distribution of Income." Journal of International Economics 12 (February 1982): 125-141.

Pulzer, Peter G. J. Political Representation and Elections in Britain. London: George Allen \& Unwin, 1967.

Registrar-General. Decennial Supplement, England \& Wales, 1921, Part II: Occupational Mortality, Fertility, and Infant Mortality. London: His Majesty's Stationery Office, 1927.

Rogowski, Ronald. Commerce and Coalitions: How Trade Affects Domestic Political Alignments. Princeton: Princeton University Press, 1989.

Snyder, Rixford Kinney. The Tariff Problem in Great Britain, 1918-1923. Stanford Studies in History, Economics, and Political Science, Vol. 5, No. 2. Stanford: Stanford University Press, 1944.

Taylor, A. J. P. English History. 1914-1945. Oxford: Oxford University Press, 1965.

Thomas, Mark. "Institutional Rigidity in the British Labour Market." In S. N. Broadberry and N. F. R. Crafts (eds.), Britain in the International Economy. New York: Cambridge University Press, 1992. 